以上の訊驗結果を総括するに、

（1）ヴィニール樹脂材料より㱔造せるパッキングは 高溫、常溫、低溫の何れの場合にてる酎麼耗性は大で、 慴動面に放んど損傷を見ないが、革パッキングは特に高 溫に於いて革緘維に脆化を生じ、文低溫に於いては硬度 变化は小であるが空気中の水分の水䅅に位つて生ずる氷 の如き固体にて摩辁をろけ易く慴動面炕著るしい倠の生 ずるを見る。

(2)ヴィニール㰾脂材料より製造せるパッキングは
高溫、常溫、低溫に於、て使用する時硬展に萻るしい变 化を生ずるる、流体圧の比較的小なる時は、使用後常温 にもどすと殆んど完全に使用前の形狀、性質を保つが、 革パッキングに於いては形狀の変化、其の他の損稘が著 るしい。

郎ち全体的に考えてがィニ一ル樹脂を材料とするパッ キッグは革を材料とするパッキングに種々の点ですぐれ ていると結諭することが出來る。

\title{
PVC 樹脂の塩素量簡易定量法
}

\author{
(昭和 25 年 10 月 25 日受理)
}

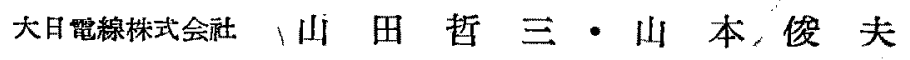

\section{1. 緒言}

塩化ヴィニール樹脂（PVC と略す）の全㙁素量を：定 量分析する事は、樹脂の純度判定或は共重合組 成の推 定等に役立つ。然し此の定量方泆の標準としては般に 用いられている方泆はカリウス洗であるが、実際にカリ ウス法を実施するにはガラス封入の面倒さや、加熱中の

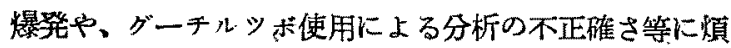
らわされる事が展々ある事は誰しる経驗される事と思 ろ。そこで数多くの実驗を行ら場合に、カリウス程の正 確度は無くとす簡便に目的定達し得る分析泆が望京れる

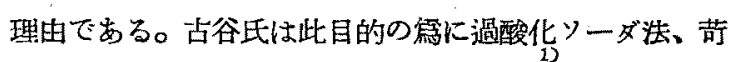
性カり愹镹泆の 2 つを提案せられているが、此方法に於 ても尚ゲーチルッボの使用や、アルカリの突沙等が実驗 者を困らせる。そこで我々は安全に操作が出來且迅速定 量を行い得る一方洗を考案したので此方法を紹介して江 湖の批判を頂きたい。

\section{2. 提案分析方法}

分析容器は約 $50 \mathrm{cc}$ 入位の磁性ルツボを用い正確に秤 量せる約 $0.5 \mathrm{~g}$ のPVCを採り約 $20 \mathrm{~g}$. 純炭酸カルシュ 一ム（前以て塩素不含を確認して置く）の中央部に試料 を埋める樣に゙してルッポに入れる。ルッボは電氣偱或は 直接バーナ一に体り徐々に加熱し $200^{\circ} \sim 500^{\circ} \mathrm{C}$ にて加熱 分解する。此際塩化ヴィニー儿樹脂は塩酸を放出しつ〉 分解し完全に此壏酸は荻酸カルシ 2 一の厚厤に捕えら
れる。最後に暫時ルッボを赤熱せしめてから窒溫に冷却 する。次にルッボの內容物をビーカーに移すと共にルッ ボ內残留物を稀硝酸にて洗いビーカーに合する。ビーカ 一には約 $200 \mathrm{cc}$ の蒸溜水と少量の确酸を加えカルシュ 一ム塩を完全に溶解せしめる。液は驹硝酸酸性に保つ。 次に $0.1 \mathrm{~N}$ 硝酸銀規定淮の一定過剩量をどーカ一内渡

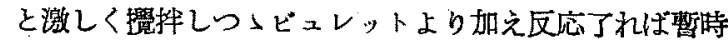
冷晊所に保存し塩化銀の沈沮を完結せしめる。头いてガ

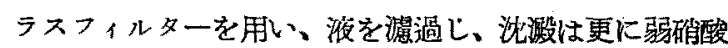
性蒸溜水にて洗い濾液と洗液を合せる。之に鉄明鐢液を 指示綝として加え $0.1 \mathrm{~N}$ 口ダン加里規定液を以て滴定し 過剩の硝酸銀を定量する。滴定の終点は永久性淡紅色の 発現を以てする。

求める $\mathrm{Cl} \%=100 \times \frac{0.003546 \times \mathrm{Acc}}{\text { 試料の } \mathrm{g} \text { 数 }}$

但し Acc =最初に加えた硙酸銀規定液の cc から逆 雕定に要したロダン加里の $\mathrm{cc}$ を引いた 数字とす。

\section{3. 基礎実䮴 a. 本法とカリウス法の比較}

\begin{tabular}{|c|c|c|c|}
\hline 供 試 料 & 本 法 & $\begin{array}{l}\text { 另吕 } \\
\text { 分析值 }\end{array}$ & 差 \\
\hline 化 $\mathrm{PVC}$ & $55.39 \%$ & $56.05 \%$ & $-0.66 \%$ \\
\hline 三菱 PVC & 51.22 & $51.69^{\circ}$ & -0.47 \\
\hline $\begin{array}{c}\text { 日本合成 P V C } \\
\text { (共重合) }\end{array}$ & 49.43 & 49.78 & -0.35 \\
\hline
\end{tabular}

上記の数字は総て過少誤差を示したが此程度の近似值 
を得れば工業分析としては充分でるると考えられる。

\section{4. 基整実驗 b. 塩化アンモンの分析}

炭酸カルシュ一ムの厚層に上る発生塭酸の捕集学確認 する急に PVC の代りに $\mathrm{NH}_{4} \mathrm{Cl}$ を用いて確認実驗を行 つた。別に $\mathrm{NH}_{4} \mathrm{Cl}$ を蒸溜水に溶解し之学同樣に $\mathrm{Cl}$ 定 量して両者を比較した。, 結果は光の通りで上く一致す る。份理諭值は $66.27 \%$ \%むる。差は $\mathrm{NH}_{4} \mathrm{Cl}$ の純度に よる。

\begin{tabular}{|c|c|c|}
\hline 方 & 分析值 $\mathrm{Cl} \%$ & 平 均 \\
\hline $\begin{array}{l}\text { 炭酸カルシューム中に } \\
\text { て加笞の場合 } \\
\mathrm{NH}_{4} \mathrm{Cl} \rightarrow \mathrm{NH}_{3}+\mathrm{HCl}\end{array}$ & $\begin{array}{l}65.91 \\
65.91 \\
66.09\end{array}$ & 65.97 \\
\hline 蒸溜水溶解定責 & $\begin{array}{l}65.92 \\
65.92 \\
65.92\end{array}$ & 65.92 \\
\hline
\end{tabular}

全部叐酸カルシュームに捕集されている。

\section{2,3 の分析例}

上記方法にて大体実鈳が充分実用に供し得る程度の正 確度を有する事を認めたので本邦製及米國製の 2，3の PVCに就て分析を実施した。其結果は次の通であつた。

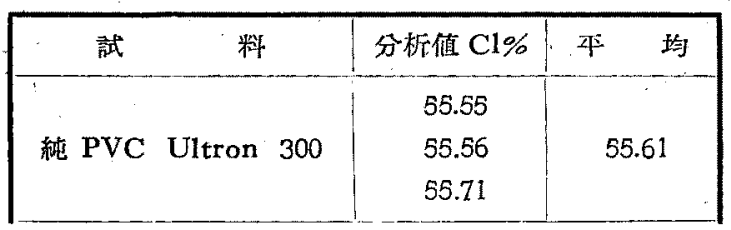

\begin{tabular}{|c|c|c|}
\hline 純 PVC 緟 化 製 & $\begin{array}{l}55.30 \\
55.32 \\
55.54\end{array}$ & 55.39 \\
\hline $\begin{array}{r}\text { 共重合体 Vycanac } \\
\text { V.Y.N.W }\end{array}$ & $\begin{array}{l}53.80 \\
53.81 \\
53.86\end{array}$ & 53.82 \\
\hline 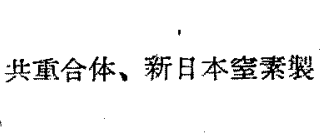 & $\begin{array}{l}53.50 \\
53.68 \\
53.95\end{array}$ & 53.71 \\
\hline 共重合体、日本合成製， & $\begin{array}{l}49.30 \\
49.43 \\
49.57\end{array}$ & 49.43 \\
\hline
\end{tabular}

6. 総括

炭酸カルシュム粉末中にて PVCを加熱分解せしめ発 生する塩酸を吸着せしめて後之を容量分析して壏素量を 測定する簡易分析方法を提案した。此方法の利点は次の 通りである。

1)カリウス封管の項雜さが無くなる

2) 白金ルツ亦やニッケルルツボを必要とせず磁製ル ツボで行ら事が出來る

3）取扱いの伦险な薬品を使用しない

4）不正確になり易いダーチルッボの使用が響けられ る

5）大量迅速に分析出來る。(容量分析である篇)

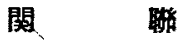

（1）古谷正泛：プラスキックの成型、加工゙ 304頁

(2) 石橋雅淁：容䭪分析奉驗指針

\section{金属とゴムとの接着}

（第 2 報） 環化コムの生成條件と接着性に就いて

(昭和 25 年 11 月 20 日受理)

日本ダンロップ護謨桃式会塥研究部 森田榮 一

1. 緒 佥

前報に於て数種の環化ゴムの数着性を比較して、その 生成條件によってその揬着性は相違することを例示し
た。Thies 氏は塩化第二錫酸をゴムに作用させて 25 〜 $105^{\circ} \mathrm{C}$ の㞒範囲の軟化点を有する種々の環化ゴムを得 て、接着用には特に 55 $65^{\circ} \mathrm{C}$ 程度で軟化するるのを選 んでいる事からる接着郕として最通の環化度があること 